„Przekłady Literatur Słowiańskich”. T. 9, cz. 3

ISSN 2353-9763 (wersja elektroniczna)

DOI $10.31261 /$ PLS.2019.09.03.03

\title{
Polska wersja Wzniesienia Milena Ruskowa
}

\section{The Polish Version of Milen Ruskov's Summit}

\author{
Kamen Rikev \\ iD https://orcid.org/0000-0002-6606-4731 \\ MARIA CURIE-SKŁODOWSKA UNIVERSITY IN LUBLIN \\ rikev@umcs.pl \\ Data zgłoszenia: 15.09 .2017 r. | Data akceptacji: 10.12 .2017 r.
}

\begin{abstract}
The article comments on Milen Ruskov's third novel Summit (The Heights / Възвишение, 2011) and its critical acclaim in Bulgaria. Set in 19th-century milieu, the revolutionary struggles and the novel's unique language have been indicated by critics as its most outstanding aspects that provoke new debates on the national and linguistic identity of contemporary Bulgarians. At the same time the novel's Polish translation by Magdalena Pytlak (Wzniesienie, 2017) poses other questions concerning the promotion of modern Bulgarian culture abroad, the translatability of Ruskov's work and the translator's strategies in terms of successfully "importing" Bulgarian literature into the Polish context.

KEYWORDS | Bulgarian literature, Bulgarian National Revival, Milen Ruskov, Magdalena Pytlak, national exclusivity, translatability of literary works
\end{abstract}


W marcu 2017 roku ukazał się polski przekład powieści Milena Ruskowa Wzniesienie ${ }^{1}$. Propozycja Wydawnictwa Uniwersytetu Jagiellońskiego daje możliwość polskim czytelnikom zapoznania się z głośną bułgarską powieścią zaledwie kilka lat po jej krajowym wydaniu, natomiast sam przekład Magdaleny Pytlak można traktować jako ewenement w najnowszym bułgarsko-polskim dialogu literackim, który zasługuje na specjalne omówienie.

Milen Ruskow (ur. w 1966 roku w Burgas) należy do fali średniego pokolenia bułgarskich tłumaczy z języka angielskiego i prozaików, którzy posiadają wyraźnie określone preferencje dotyczące tematyki i stylu literackiego. Akcja jego dwóch pierwszych powieści (Джобна енииклопедия на мистериите, 2004 oraz Захвърлен в природата, 2008) rozgrywa się w czasach średniowiecznych oraz wczesnonowożytnych i traktuje o życiu umysłowym Europy Zachodniej. Nawiązania do renesansowego kosmopolityzmu, do egzotyki i ezoteryki fragmentarycznej narracji, która przywołuje zapomniane postaci i ich osobliwe idee, łączy się z ożywieniem i rozwijaniem estetyki bułgarskiego postmodernizmu. Historyczna pamięć i ironia wobec potężnych intelektualnych tradycji, ucieczka w świat wyobrażony, wszechogarniająca nostalgia, rozkoszowanie się konstruowaniem własnych historii - to elementy, które ujawniły nieprzewidywalny potencjał Ruskowa jako subtelnego prozaika, unikającego typowo rodzimej tematyki. Mało kto przewidywał, że trzecia powieść autora nie tylko zostanie oparta na narodowej przeszłości, lecz z nieoczekiwanej perspektywy odnowi debatę nad tożsamością zbiorową oraz sposobami postrzegania języka bułgarskiego w kategorii sacrum.

Powieść Wzniesienie (Възвищение), wydana w 2011 roku przez renomowane płowdiwskie wydawnictwo „Żanet $45^{\text {” }}$, zyskała natychmiastowy rozgłos. W 2014 roku Ruskow stał się laureatem Nagrody Literackiej Unii Europejskiej, a o uznaniu czytelników świadczyły kolejne dwa wydania utworu. Ważniejsze jednak wydaje się to, że książkę natychmiast okrzyknięto "przyszłą klasyką"” oraz że podjęto próby jej analizy i interpretacji w szerokim kontekście rozwoju literatury narodowej.

Zaledwie kilka miesięcy po publikacji powieści uznany krytyk i historyk literatury Swetłozar Igow stwierdził, że Wzniesienie stanowi „nowe artystyczne spojrzenie na narodową rewolucję oraz tematykę, na której bazując [Christo] Botew, [Iwan] Wazow i [Zachary] Stojanow, stworzyli swoje

1 M. Ruskow, 2017: Wzniesienie. M. Pytlak, tłum. Kraków, Wydawnictwo UJ, 416 s.

2 М. Русков, 2011: Възвишение. Пловдив, „Жанет 45”, 408 s.

3 М. Новков, 2012: Историята/Истории или Вбзвичение на физиката, успоредно четене. „Литературен вестник”, нр. 5, s. 6. Dostępne w Internecie: http://www.bsph. org/members/files/pub_pdf_1260.pdf [dostęp: 10.11.2018]. Tu i dalej tłumaczenia z tekstów bułgarskich moje - K.R. 
arcydzieła” ${ }^{4}$. Nawiązując do pierwszej powieści Ruskowa, Igow proponuje klucz do interpretacji utworu w charakterze „kieszonkowej encyklopedii” epoki bułgarskiego odrodzenia narodowego, czyli emblematycznego okresu zarazem martyrologii i bohaterstwa, powstańczych klęsk i wyzwolenia Bułgarów spod panowania Imperium Osmańskiego. W konkluzji stwierdza, że Wzniesienie to „powieść obrazująca początek tworzenia w świadomości indywidualnej tego, co nazywamy historyczną i narodową pamięcią".

Opinia Igowa, dotycząca osadzenia powieści w epoce odrodzenia i oddawania jej specyfiki, jest zbieżna z ocenami kolejnych czołowych krytyków, którzy podkreślają walory nie tylko estetyczne, lecz także narodowe. Warto przywołać poglądy Nikołaja Aretowa („powieść można interpretować w duchu nowego spojrzenia rewizjonistycznego na wielką narrację o narodowej rewolucji”) ${ }^{5}$, Złatka Angełowa („powieść ta ... będzie pełniła funkcję jednoczenia narodu”) ${ }^{6}$, Dimityra Kamburowa („ambicją pierwszoosobowej narracji u Ruskowa jest wyartykułowanie niezmąconej prawdy o odrodzeniu narodowym") ${ }^{7}$, Inny Pelewej („powieść ta jest największym ewenementem w najnowszej literaturze bułgarskiej”) ${ }^{8}$, Mładena Właszkiego („Ruskow komponuje niezrównaną opowieść o bułgarskim odrodzeniu i «urodzonym»w nim «nowożytnym» Bułgarze") ${ }^{9}$. Angielski tłumacz literatury bułgarskiej (w tym Ruskowa) Christopher Buxton również pokusił się o barwne stwierdzenie, że „Milen Ruskow jest bułgarskim Cervantesem"10.

4 С. Игов, 2011: Роман за българското Risorgimento. „Електронно списание LiterNet”, нр. 10 (143). Dostępne w Internecie: http://www.kultura.bg/bg/article/ view/18937 [dostęp: 10.11.2018].

5 Н. Аретов, 2012: Нагоре! Николай Аретов [приватни блог]. Dostępne w Internecie: http://aretov.queenmab.eu/archives/criticism/86-review/134-height.html [dostęp: 10.11.2018].

6 3. Ангелов, 2012: Възвишената красота на езика. Мисли по време на четенето на „Възвишение “от Милен Русков, подредени след това. „Литературен вестник”, нp. 42, s. 7. Dostępne w Internecie: http://www.bsph.org/members/files/pub_pdf_1312. pdf [dostęp: 10.11.2018].

7 Д. Камбуров, 2012: Първолични носталгии. „Възвищение” от Милен Русков и „Физика на тъгата” от Георги Господинов. „Култура”, нр. 35 (2697). Dostępne w Internecie: http://www.kultura.bg/bg/article/view/20198 [dostęp: 10.11.2018].

8 И. Пелева, 2013: ХІХ век - днес и на български. „Електронно списание LiterNet”, нр. 10 (167). Dostępne w Internecie: http://liternet.bg/publish20/i_pe leva/XIX-vek-dnes.htm [dostęp: 10.11.2018].

9 М. Влашки, 2015: Из „Романология ли? Съвременният български роман между употребата и експеримента". Контексти на днешния български роман. „Електронно списание LiterNet”, нр. 5 (186). Dostępne w Internecie: http://liternet. bg/publish26/mladen-vlashki/romanologia.htm [dostęp: 10.11.2018].

10 C. Buxton, 2012: Summit by Milen Ruskov. Dostępne w Internecie: http://christopher buxton.com/index.php/summit-by-milen-ruskov/ [dostęp: 10.11.2018]. 
Paralelnie z analizami dotyczącymi „narodowotwórczego" historycznego kontekstu za wyjątkowy atut Wzniesienia uznano jego niepowtarzalny język. Formalnie narrację prowadzi główny bohater Giczo, hajduk-rewolucjonista, który opisuje swoje podróże po bułgarskich ziemiach śladem Wasyła Lewskiego ${ }^{11}$, cytuje i interpretuje prawdziwe i zmyślone utwory z epoki, rozważa nad etymologią niektórych bułgarskich słów i miejscowości. W swoim trafnym podsumowaniu polska tłumaczka Magdalena Pytlak stwierdza, że Ruskow „wymyślił na potrzeby swej literackiej wizji nowy język. Język ten jest mieszanką dialektu z okolic miasta Koteł, języka odrodzeniowego piśmiennictwa [...], słów zaczerpniętych z dziewiętnastowiecznych słowników oraz własnej językowej fantazji i ogromnego poczucia humoru. Jest to zatem język będący grą jednocześnie z tradycją i współczesnością"12.

Rodzime oceny dotyczące języka Wzniesienia koncentrują się wokół niezwykłości, wyjątkowości, eksperymentalności tego utworu. Prawdą jest, że w porównaniu z polską tradycją proza bułgarska nie posiada narratorów jak Jan Chryzostom Pasek, ani mistrzów stylizacji staroświeckiej mowy jak Henryk Sienkiewicz. W tej perspektywie powieść Ruskowa wpisuje się raczej w słowną, gramatyczną i ortograficzną polifonię epoki odrodzenia, która umożliwiła projekt emancypacji z tradycji języka cerkiewnosłowiańskiego. Zgadzając się z pierwotnym poglądem samego autora, wyrażonym $\mathrm{w}$ wywiadach, który dotyczy nieprzekładalności powieści na obce języki ${ }^{13}$, bułgarscy krytycy akcentują przekonanie o wyjątkowym charakterze utworu - zarówno dzięki swoistemu językowi artystycznemu, jak i specyfice odrodzeniowych realiów i wartości, stanowiących sedno narodowego sacrum.

Czynnikiem przyczynającym się do zaostrzenia ocen krytycznoliterackich stał się fakt, że powieść Ruskowa opublikowano i interpretowano paralelnie z Fizyka smutku Georgiego Gospodinowa. O ile Fizyka jest uniwersalna w swoich tematyce i przesłaniach, „otwarta” na międzynarodowych czytelników oraz tłumaczy, o tyle Wzniesienie odsyła do stricte bułgarskiego klucza w celu zrozumienia zawartych w utworze sensów.

We artykule z 2016 roku $^{14}$ zaproponowałem specyficzny ogląd Wzniesienia. Wychodząc z założenia, że w swojej zasadniczej istocie powieść nie oferuje

11 Wasyl (Wasil) Lewski (1837-1873) - rewolucjonista, ideolog walk o wyzwolenie Bułgarii, bohater narodowy.

12 M. Pytlak, 2017: Od ttumaczki. W: M. Ruskow: Wzniesienie. Kraków, Wydawnictwo UJ, s. 7.

13 Por. М. Витанова, 2011: Помогни ми да те возвися. „Култура”, нр. 35 (2653), s. 3; Цв. Трифонова, 2014: Късни вариации около романа „Възвишение”. „Факел.бг”. Dostępne w Internecie: http://www.fakel.bg/index.php?t=3505 [dostęp: 10.11.2018]; М. Новков, 2012: Историята/Истории..., s. 6; 3. Ангелов, 2012: Възвишената красота..., s. 7.

14 К. Рикев, 2016: Романът „Възвишение” в съвременния български литературен контекст. „Език и литература”, нр 3-4, s. 74-88. 
kolejnej narracji o narodowym odrodzeniu (s. 76) ${ }^{15}$, broniłem tezy, że poprzez naśladowanie lub raczej przypominanie wzorców z epoki książka wpisuje się w kategorię współczesnej, swoistej literackiej trawestacji całego korpusu bułgarskiej prozy o walkach rewolucjonistów. Z takiej perspektywy Ruskow kieruje przesłania dzieła do swej teraźniejszości i współczesnych mu czytelników (s. 77), a dziewiętnastowieczne dekoracje mają na celu zapewnienie odpowiedniego tła - zarazem emocjonalnego i boleśnie rozpoznawalnego - do rozważań nad zawiłymi kwestiami tożsamości zbiorowej w XXI wieku. Innymi słowy, przesłania Wzniesienia dotyczą par excellence tzw. okresu bułgarskiego przejścia do demokracji (българския Преход) (s. 79-82). Natomiast zarówno język, jak i akcja utworu narzucają pytanie o potencjał rodzimych odbiorców w interpretacji odrodzeniowej tematyki, w świetle współczesnej kultury rozrywkowej (chociaż zarówno intelektualnej), grającej zasadami „staroświeckości” i różnego rodzaju stylizacji, do których można zaliczyć prozę Umberta Ecco lub telewizyjne seriale kostiumowe (s. 87).

Niezależnie od wyboru strategii interpretatorskich pewnym wydaje się fakt, że w drugim dziesięcioleciu XXI wieku bułgarscy odbiorcy niezbicie odczuwają nostalgię za tematyką hajductwa i narodowego bohaterstwa, jak również potwierdzają głębokie przywiązanie do językowego demokratyzmu i dziwaczności dziewiętnastowiecznych działaczy kultury. Ponadto celowa wulgaryzacja języka prozatorskiego, jako chwyt rynkowy, z pewnością przyczyniła się do poszerzenia kręgu rodzimych odbiorców tej pokaźniej książki (ponad 400 stron).

W świetle jednoznacznie pozytywnej recepcji powieści Milena Ruskowa oczywistym jawi się fakt, że próby tłumaczenia utworu na języki obce stanowią ogromne wyzwanie, a opublikowanie przekładu Wzniesienia będzie rodziło kolejne pytania, dotyczące walorów najnowszej bułgarskiej literatury i przetłumaczalności jej typowo narodowych realiów. Dlatego wyraziłem przekonanie, że polska wersja powieści w tłumaczeniu Magdaleny Pytlak jest ewenementem przede wszystkim dla promocji współczesnej kultury bułgarskiej za granicą, natomiast jakość tłumaczenia można oceniać dopiero po analizie danych rynkowych i opiniach polskich krytyków ${ }^{16}$. Nie ulega wątpliwości

15 Podobne stanowiska wyrażają: М. Новков, 2012: Историята/Истории..., s. 7 („[...] patrząc szczerze [...] Wzniesienie [...] to nie powieść o Bułgarskim odrodzeniu i powstańczych ruchach”); Б. Пенчев, 2011: Високо, високо, високо. „Капитал Light”, нр 47 (Wzniesienie pokazuje „jakby odwrotną stronę Odrodzenia. [...] Ruskow rozmieszcza nie tylko autorytety, ale samą koncepcję o „wysokim” i „niskim” jako oddzielne kategorie, o których powinno się opowiadać w odmienny sposób”).

16 К. Рикев, 2017а: За превода на една книга и преводимостта на много равнища. „Език и литература”, нр 1-2, s. 269. Dostępne w Internecie: http://www.ezik-i-lite ratura.eu/2017/1-2/24-K.Rikev-rec-BG.pdf [dostęp: 10.11.2018]. 
jednak, że polska wersja utworu Ruskowa i translatorskie strategie M. Pytlak będą funkcjonować w zupełnie innych warunkach, które automatycznie pozbawiają powieść doniosłości kontekstu narodowego i jej unikalności językowej.

W przygotowywaniu recenzji dla czasopisma „Език и литература” skierowałem konkretne pytania do tłumaczki. Jestem wdzięczny p. M. Pytlak za szczere i szczegółowe odpowiedzi dotyczące historii przekładu Wzniesienia. W tym przypadku książką zainteresował się wydawca, ponieważ jako nagrodzona Europejską Nagrodą Literacką, automatycznie znalazła się na liście pozycji sugerowanych do przekładu w ramach Europejskiego Grantu na tłumaczenia literackie. W ten sposób Wzniesienie stało się pierwszą książką, której propozycję tłumaczenia otrzymała M. Pytlak. Powszechna praktyka wygląda jednak inaczej: zazwyczaj tłumacze literatury bułgarskiej przesyłają propozycje i fragmenty przekładu do wydawców. Zważywszy na nietypowe okoliczności, tłumaczka stanęła przed nie lada dylematem — znając powieść Ruskowa, była pełna wątpliwości wobec trudnego przedsięwzięcia, jednocześnie wiedziała, że to propozycja "jedna na milion".

Praca nad przekładem zajęła M. Pytlak prawie dwa lata. Liczne spotkania $\mathrm{z}$ autorem podczas procesu translacji zadecydowały o wyborze własnych strategii przekładu i rezygnacji z innych pomysłów. Tłumaczka nie ukrywa, że bułgarskie głosy o nieprzekładalności tej powieści stanowiły dodatkowy impuls do utworzenia jej polskiej wersji.

Głównym problemem w rozważaniach nad obcojęzycznym istnieniem Wzniesienia jest kwestia radzenia sobie $\mathrm{z}$ archaizacją i stylizacją, które charakteryzują oryginał. Strategia M. Pytlak wymuszona była brakiem polskiego odpowiednika na jakimkolwiek poziomie gry językowej Ruskowa. Należy dodać, że historia języka polskiego zdecydowanie różni się od linii rozwojowej języka bułgarskiego. Ostatecznie strategia tłumaczki została oparta na dwóch filarach. Pierwszy dotyczył rezygnacji z poszukiwań polskiego odpowiednika językowego na poziomie regionu i rejestru, co uzasadnia również starania dotyczące unikania internacjonalizmów. W związku $\mathrm{z}$ tym nawet te internacjonalizmy, które pojawiają się w oryginale, tłumaczka zastępowała słowiańskimi odpowiednikami. Drugi z filarów związany był z potrzebą zachowania wrażenia nie tyle obcości kulturowej i językowej, co przynajmniej pewnej stylistycznej gry.

Kolejnym wyzwaniem dla tłumaczy Wzniesienia jest sprawa zwulgaryzowanego - aczkolwiek w celach estetycznych - języka. Ponieważ autor osiągał wulgarność poprzez użycie jednego słowa w jego najróżniejszych formach, a polski ekwiwalent tego samego słowa jest jednoznacznie bardziej ordynarny, M. Pytlak wybrała strategię budowania przekładu nie na kon- 
kretnym wulgaryzmie, lecz wokół danej metafory. Dlatego w polskim przekładzie pojawił się pies, który w zależności od użytego idiomu może brzmieć mniej lub bardziej niecenzuralnie, posiadając przy tym bogaty potencjał stylistyczny.

Za ważny element polskiego wydania powieści uważam krótką przedmowę Od tłumaczki ${ }^{17}$, która, naśladując styl przedmowy autora (Od autora, s. 6), pełni wieloznaczną funkcję. M. Pytlak ujawnia w niej swoje podejście do utworu w roli tłumacza, lecz również literaturoznawcy i krytyka w pełni świadomego odpowiedzialności za adekwatną (i na wszystkich płaszczyznach odmienną od bułgarskiej) recepcję Wzniesienia w Polsce ${ }^{18}$. Warto również podkreślić, że Informacja o tekście w oryginale Ruskowa znajduje się po zacytowanym fragmencie utworu odrodzeniowego filologa Konstantina Fotinowa. W polskim wydaniu kolejność tekstów inicjalnych jest zmieniona: najpierw pojawia się krótki fragment Od autora, podniesiony do rangi swoistej przedmowy od samego Ruskowa, następnie zamieszczone są słowa Od tłumaczki, a dopiero potem cytat Fotinowa. Wplatając więc głos tłumaczki w tkankę inicjujących rozdziałów powieści, uwidoczniona zostaje decyzja wydawcy, by podkreślić rolę translatora jako pełnoprawnego uczestnika w procesie literackim, który staje się dla czytelników polskich zarówno komentatorem, jak i pewnego rodzaju "neutralizatorem” autentycznego bałkańskiego kontekstu.

Jakie są, według mnie, ważniejsze punkty krótkiej przedmowy M. Pytlak kierowanej do zagranicznych odbiorców powieści? Po pierwsze, Wzniesienie wymaga specjalnego komentarza tłumacza jeszcze w częściach wstępnych jako deklaracji swoistej pozycji utworu i jego osadzenia w specyficznych realiach bałkańskich. Po drugie, taki gest jest delikatnym, lecz wyrazistym świadectwem o nie-ekskluzywności Milena Ruskowa jako autora dzieła literackiego przetłumaczonego na obcy język. Przeciwnie: przynajmniej część kompetencji autora powinna zostać „oddana” tłumaczowi w związku z problematyczną ekwiwalencją między oryginałem a przekładem. Wyrażając swoje strategie, ale także obawy dotyczące przekładu, M. Pytlak w sposób rzetelny i odpowiedzialny przyjmuje ryzyko podjętego przedsięwzięcia. Fakt ten świadczy również o zwiększonej uwadze tłumaczki poświęconej adekwatnej recepcji utworu przez Polaków.

Kolejnym atutem przedmowy tłumaczki jest ujawniająca się perspektywa literaturoznawcza. Stanowiska bułgarskich krytyków dotyczą głównie eksperymentalnego języka powieści, natomiast Pytlak kładzie akcent na ludyczność

17 M. Pytlak, 2017: Od ttumaczki..., s. 7-8.

18 Рог. К. Рикев, 2017b: Пролегомени към полския превод на „Възвищение”. „Език и литература", нр. 1-2, s. 273-275. Dostępne w Internecie: http://www.ezik-i -literatura.eu/2017/1-2/25-K.Rikev,M.Pitlak BG.pdf [dostęp: 10.11.2018]. 
fabuły i specyficzną konstrukcję języka Ruskowa. Tłumaczka uzasadnia swój wybór funkcjonalnych ekwiwalentów wymowy, który motywuje chęcią uniknięcia ewentualnej polonizacji dzieła.

Wszystkie elementy w tekście Od tłumaczki prowadzą do szerszego pytania o troskę skutecznej, czyli niedosłownej i zawsze funkcjonalnej, recepcji współczesnej bułgarskiej kultury w Polsce. Okazuje się, że w przypadku Wzniesienia Milena Ruskowa godne do literackiego „importu” są nie tyle konteksty bułgarskiego sacrum, lecz przeciwnie - elementy egzotycznej zabawy historią z Bałkanami w tle.

Do sformułowania powyższego wniosku skłania też okładka powieści, przedstawiająca działaczy powstania ilindeńskiego z 1903 roku. Dzięki takiej fotografii trudno oprzeć się wrażeniu, że bułgarska rzeczywistość w oczach dzisiejszych Polaków pozostaje w granicach stereotypizacji, według której pomiędzy 1872 a 1903 rokiem na Bałkanach nic znaczącego się nie wydarzyło.

U schyłku 2017 roku odbyła się premiera filmu Wzniesienie ${ }^{19}$, którego akcja ściśle podąża za powieściową fabułą. M. Ruskow odgrywał w produkcji aktywną rolę scenarzysty wraz z Wiktorem Bożinowem i Neli Dimitrową. W tym samym roku ukazała się jego czwarta powieść - Czamkorija (Чамкория, 2017), która zachowuje formuły znane z poprzedniego utworu: ludyczną, zarchaizowaną grę językową bohatera-narratora w nostalgicznych bułgarskich sceneriach.

\section{Literatura}

Buxton C., 2012: Summit by Milen Ruskov. Dostępne w Internecie: http://christop herbuxton.com/index.php/summit-by-milen-ruskov/ [dostęp: 10.11.2018].

Pytlak M., 2017: Od tłumaczki. W: M. Ruskow: Wzniesienie. Kraków, Wydawnictwo UJ, s. 7-8.

Ruskow M., 2017: Wzniesienie. M. Pytlak, tłum. Kraków, Wydawnictwo UJ, 416 s.

Ангелов 3., 2012: Възвишената красота на езика. Мисли по време на четенето на „Възвишение” от Милен Русков, подредени след това. „Литературен вестник”, нр. 42 (19-31.12), s. 6-7. Dostępne w Internecie: http://www.bsph.org/members/files/pub_pdf_1312.pdf [dostęp: 10.11.2018].

Аретов Н., 2012: Нагоре! Николай Аретов [приватни блог]. Dostępne w Internecie: http://aretov.queenmab.eu/archives/criticism/86-review/134-height. html [dostęp: 10.11.2018].

19 Възвишение (Heights / The Liberators). Reż. W. Bożinow. Serpentine Film \& TV Production - All Stars In - Bulfilm - Bulgarian National Film Center, 2017. 
Витанова М., 2011: Помогни ми да те возвися. „Култура”, нр. 35 (2653), s. 3. Dostępne w Internecie: http://www.kultura.bg/bg/print_article/view/18894 [dostęp: 10.11.2018].

Влашки М., 2015: Из „Романология ли? Съвременният български роман между употребата и експеримента". Контексти на днешния български роман. „Електронно списание LiterNet”, нр. 5 (186). Dostępne w Internecie: http://liternet.bg/publish26/mladen-vlashki/romanologia.htm [dostęp: 10.11.2018].

Игов С., 2011: Роман за българското Risorgimento. „Електронно списание LiterNet”, нр. 10 (143). Dostępne w Internecie: http://liternet.bg/pub lish/sigov/milen-ruskov-vyzvishenie.htm; też w: „Култура”, 2011 (28.10), нp 36 (2654), s. 8. Dostępne w Internecie: http://www. kultura.bg/bg/article/ view/18937 [dostęp: 10.11.2018].

Камбуров Д., 2012: Първолични носталгии. „Възвишение” от Милен Русков и „Физика на тъгата” от Георги Господинов. „Култура”, нр. 35 (2697). Dostępne w Internecie: http://www.kultura.bg/bg/article/view/20198 [dostęp: 10.11.2018].

Новков М., 2012: Историята/Истории или Възвишение на физиката, успоредно четене. „Литературен вестник”, нр. 5 (8-14.02), s. 6-7. Dostępne w Internecie: http://www.bsph.org/members/files/pub_pdf_1260.pdf [dostęp: 10.11.2018].

Пелева И., 2013: ХІХ век - днес и на български. „Електронно списание LiterNet”, нр. 10 (167). Dostępne w Internecie: http://liternet.bg/publish20/i_pe leva/XIX-vek-dnes.htm [dostęp: 10.11.2018].

Пенчев Б., 2011: Високо, високо, високо. „Капитал Light”, нр. 47. Dostępne w Internecie: http://www.capital.bg/light/revju/knigi/2011/11/24/1211306_ visoko_visoko_visoko/ [dostęp: 10.11.2018].

Рикев К., 2016: Романбт „Възвишение” в съвременния български литературен контекст. „Език и литература”, нр 3-4, s. 74-88.

Рикев К., 2017а: За превода на една книга и преводимостта на много равнища. „Език и литература”, нр. 1-2, s. 269-272. Dostępne w Internecie: http://www.ezik-i-literatura.eu/2017/1-2/24-K.Rikev-rec-BG.pdf [dostęp: 10.11.2018].

Рикев К., 2017b: Пролегомени към полския превод на „Възвишение”. „Език и литература”, нр. 1-2, s. 273-275. Dostępne w Internecie: http://www.ezik-iliteratura.eu/2017/1-2/25-K.Rikev,M.Pitlak BG.pdf [dostęp: 10.11.2018].

Русков М., 2011: Възвишение. Пловдив, „Жанет 45”, 408 s.

Трифонова Цв., 2014: Късни вариации около романа „Възвичение”. „Факел.бг”. Dostępne w Internecie: http://www.fakel.bg/index.php?t=3505 [dostęp: 10.11.2018]. 


\section{Камен Рикев}

\section{Полската версия на Възвишение от Милен Русков}

PЕЗЮМЕ | Статията коментира появата на третия роман на Милен Русков Възвищение (2011) и неговата позитивна критическа рецепция в България. Разположен в декори от XIX век, революционните борби и уникалният език на романа провокират нови дебати върху националната и езикова идентичност на съвременните българи. Същевременно полският превод на романа (Wzniesienie, 2017), дело на Магдалена Питлак, поставя нови въпроси, свързани с промоцията на съвременната българска култура зад граница, преводимостта на Русковата творба и преводаческите стратегии за успешен „внос“ на българска литература в днешния полски контекст.

КлЮчОвИ думИ българска литература, Българско възраждане, Милен Русков, Магдалена Питлак, национална изключителност, преводимост на литературния текст

\section{Kamen Rikev}

\section{The Polish Version of Milen Ruskov's Summit}

SUMMARY | The article comments on Milen Ruskov's third novel Summit (The Heights / Възвичение, 2011) and its critical acclaim in Bulgaria. Published in the same year as Georgi Gospodinov's Physics of Sorrow (Физика на тъгата), Ruskov's work was almost unanimously lauded as a 21st-century literary phenomenom in Bulgaria. In contrast with Gospodinov's book, it remains deeply rooted in the national historical context and, in addition, seems to be virtually untranslatable. Set in 19th-century milieu, the depicted revolutionary struggles and the novel's unique language have been indicated by critics as the novel's most outstanding features that provoke new debates on the national and linguistic identity of contemporary Bulgarians. At the same time the novel's Polish translation by Magdalena Pytlak (Wzniesienie, 2017) poses other questions concerning the promotion of modern Bulgarian culture abroad, the translatability of Ruskov's work and the translator's strategies in terms of successfully "importing" Bulgarian literature into the Polish context. Pytlak's version of Summit reveals her role as the translator and, simultaneously, constitutes a competent guide to the artistic world created by Ruskov. These features make the Polish translation of Summit a notable event in the recent Polish-Bulgarian cultural dialogue. Its success, however, could only be measured by the book's market value and the future analyses of literary scholars.

KEYWORDS | Bulgarian literature, Bulgarian National Revival, Milen Ruskov, Magdalena Pytlak, national exclusivity, translatability of literary works

KAMEN RIKEV | dr, adiunkt w Zakładzie Białorutenistyki i Bułgarystyki IFS UMCS w Lublinie. Badacz poezji staropolskiej, literatury bułgarskiej XX wieku i kultur bałkańskich. Autor antologii literatury staropolskiej od średniowiecza do oświecenia Зубър, видра и паун (2008) oraz Два зубъра и муза (2014), tłumacz literatury polskiej. 